\title{
Synthesis and properties of novel poly(p-xylylene)s with aliphatic substituents
}

\author{
Michael Ishaque, Seema Agarwal, Andreas Greiner*
}

Philipps-University Marburg, Department of Chemistry and Scientific Centre for Materials Science, Hans-Meerwein-Str., 35032 Marburg, Germany;

Fax +49-6421-2825785; greiner@mailer.uni-marburg.de

(Received: May 28, 2002; published: July 3, 2002)

\begin{abstract}
Poly(p-xylylene)s (PPX) with aliphatic substituents at the alpha position were synthesized by chemical vapor deposition (CVD) via vapor phase pyrolysis of $\alpha$-chloro-1,4-xylenes, or by base-induced dehydrohalogenation of $\alpha$-chloro-1,4xylenes (Gilch route). These PPXs are soluble under ambient conditions in organic solvents. The glass transition temperature of the tert-butyl substituted PPX is remarkably high. Good thermal stability under nitrogen was observed for the trifluoromethyl substituted PPX. A functionalized compound suitable for polymer analogous reactions is the norbornenyl substituted PPX.
\end{abstract}

\section{Introduction}

PPX (trade name parylene N) represents an important class of aromatic polyhydrocarbons, which gains increasing significance due to many promising properties for a variety of applications. PPXs can be synthesized by CVD without action of any solvent or by solution based chemistry involving a variety of different $\mathrm{C}-\mathrm{C}$ bond forming reactions [1,2]. Efficient CVD routes to PPXs are based upon vapor phase pyrolysis of [2.2]paracyclophanes [3] or diesters of $\alpha, \alpha^{\prime}$-dihydroxy-1,4-xylene [4], $\alpha, \alpha^{\prime}$-dibromo-1,4-xylenes in the presence of $\mathrm{Zn} / \mathrm{Cu}$ [5], or $\alpha$-bromo-1,4-xylenes [6] at reduced pressure. In a recent contribution, Lahann et al. expanded the vapor phase pyrolysis of paracyclophanes to functionalized PPXs $[7,8]$. The so-called Gilch route yields high molecular weight PPXs by solution-based chemistry if the resulting PPX derivatives are organosoluble under ambient conditions. The choice of the synthetic route for realization of a particular PPX derivative depends on several key issues, including synthetic access to starting materials which has prevented up to now the realization of many PPX derivatives and with that the exploitation of the full potential of this promising class of polymers. It should be noted here that the term starting material as precursor has been coined instead of monomers since the actual monomers, quinodimethanes, are formed in situ from the starting material, independently from the nature of the polyreaction. It should also be stated that it is not clear yet whether the polyreaction of quinodimethanes is a true polymerization or a polyrecombination reaction. As long as this is the case, it is most accurate to refer to a polyreaction.

To the best of our knowledge, PPXs with alkyl substituents in the alpha position are only known for methyl substituted PPXs which were obtained by reaction of $p$-diiso- 
propylbenzene with peroxides [9]. Therefore we report here on the synthesis of PPXs with aliphatic substituents at the $\alpha$-position either by CVD or by the Gilch route. These new PPX derivatives offer improved features or novel perspectives.

\section{Experimental part}

\section{Materials}

All reactions were carried under inert gas atmosphere. All solvents were dried and distilled prior to use by standard technologies.

\section{Measurements}

IR spectroscopy was performed using a Perkin Elmer FT-IR 1600 ( $\mathrm{KBr}$ pellets). ${ }^{1} \mathrm{H}$ NMR spectra $(300 \mathrm{MHz}),{ }^{13} \mathrm{C}$ NMR spectra $(75 \mathrm{MHz})$ and COSY spectra were recorded on a Bruker AC 300. The COSY experiments were performed in the conventional manner using 180 time increments, each of $1 \mathrm{~K}$ points, over a 8.414 ppm spectral window. The f1 time domain data were zero filled to a $1 \mathrm{~K} \times 0.256 \mathrm{~K}$ matrix, and both directions were multiplied by an unshifted sine-bell function before Fourier transformation. ${ }^{19} \mathrm{~F}$ NMR spectra $(188 \mathrm{MHz})$ were recorded on a Bruker AC 200. Differential scanning calorimetry (DSC) measurements were performed by means of a Mettler DSC 20 in standard aluminium pans with a heating rate of 10 $\mathrm{K} /$ min. Gel permeation chromatography (GPC) was performed with tetrahydrofuran (THF) as solvent and a set of $5 \mu \mathrm{m}$ mixed bead columns (PSS) and a Viscotek detector. GPC molecular weight analysis was performed by universal calibration

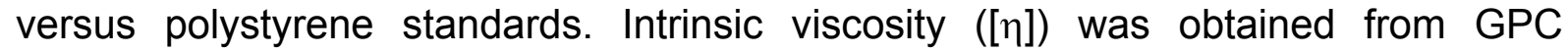
analysis using a viscodetector and universal calibration.

\section{Synthesis of 2,2,2-trifluoro-1-(4-methylphenyl)ethan-1-one, 3}

A three-necked flask equipped with stirring bar, reflux condenser and a dropping funnel was charged with $6.07 \mathrm{~g}$ of $\mathrm{Mg}(250 \mathrm{mmol})$ and $30 \mathrm{ml}$ of THF. $42.75 \mathrm{~g}$ of 1 (250 mmol) was dissolved in $80 \mathrm{ml}$ of THF and added dropwise to the Mg slurry. The reaction was stirred and heated to reflux for another hour after completion of addition. After cooling of the reaction mixture to $20^{\circ} \mathrm{C}, 11.04 \mathrm{~g}$ of trifluoroacetic acid (100 $\mathrm{mmol}$ ) dissolved in $90 \mathrm{ml}$ of THF was added dropwise. After completion of addition, the reaction mixture was heated to reflux for $2 \mathrm{~h}$. The reaction mixture was quenched after cooling by addition of $200 \mathrm{ml}$ of saturated $\mathrm{NH}_{4} \mathrm{Cl}$ solution. The mixture was extracted with diethyl ether and the combined organic extracts were dried over $\mathrm{Na}_{2} \mathrm{SO}_{4} .3$ was isolated by fractionated vacuum distillation; b.p. $35-40^{\circ} \mathrm{C}, 1 \mathrm{mbar}$. Yield $10.34 \mathrm{~g}(55 \mathrm{mmol}), 55 \%$ (based on trifluoroacetic acid).

IR (KBr, $\left.\mathrm{cm}^{-1}\right)$ : $3044 \mathrm{~m} ; 2928 \mathrm{~m} ; 1713 \mathrm{~s} ; 1607 \mathrm{~s} ; 1568 \mathrm{w} ; 1514 \mathrm{w} ; 1338 \mathrm{~m} ; 1177 \mathrm{~s} ;$ $939 \mathrm{~s} ; 835 \mathrm{~s} ; 752 \mathrm{~s}$.

${ }^{1} \mathrm{H}$ NMR $\left(\mathrm{CDCl}_{3}, \delta\right.$ in ppm): 2.44 (s, $\left.3 \mathrm{H},-\mathrm{C}(1) \underline{\mathrm{H}}_{3}\right) ; 7.33$ (d, $\left.J=7.8 \mathrm{~Hz}, 2 \mathrm{H}, \operatorname{Ar}(\mathrm{C} 3) \underline{\mathrm{H}}\right)$; $7.96(\mathrm{~d}, J=7.8 \mathrm{~Hz}, 2 \mathrm{H}, \operatorname{Ar}(\mathrm{C} 4) \underline{\mathrm{H}})$.

${ }^{13} \mathrm{C} \mathrm{NMR}\left(\mathrm{CDCl}_{3}, \delta\right.$ in ppm): $21.5\left(-\underline{\mathrm{CH}}_{3}\right) ; 116.8\left(\mathrm{q},{ }^{1} \mathrm{~J}=290 \mathrm{~Hz},-\underline{\mathrm{CF}}_{3}\right) ; 127.4(\mathrm{Ar} \underline{\mathrm{C}})$;

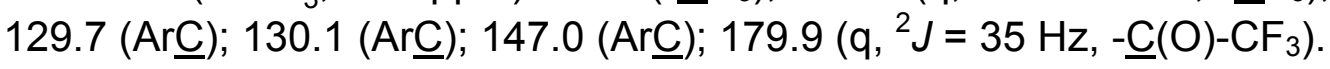




\section{Synthesis of 2,2-dimethyl-1-(4-methylphenyl)propan-1-ol, 4a}

A three-necked flask equipped with stirring bar, reflux condenser and a dropping funnel was charged with $2.79 \mathrm{~g}$ of $\mathrm{Mg}(115 \mathrm{mmol})$ and $30 \mathrm{ml}$ of THF. $18.80 \mathrm{~g}$ of 1 $(110 \mathrm{mmol})$ was dissolved in $80 \mathrm{ml}$ of THF and added dropwise to the Mg slurry. After completion of addition, the reaction was stirred and heated to reflux for another hour. After cooling of the reaction mixture to $20^{\circ} \mathrm{C}, 7.90 \mathrm{~g}$ of $2 \mathrm{a}(92 \mathrm{mmol})$ dissolved in $90 \mathrm{ml}$ of THF was added dropwise. After completion of addition, the reaction mixture was heated to reflux for $2 \mathrm{~h}$. After cooling, the reaction mixture was quenched by addition of $200 \mathrm{ml}$ of saturated $\mathrm{NH}_{4} \mathrm{Cl}$ solution. The mixture was extracted with diethyl ether and the combined organic extracts were dried over $\mathrm{Na}_{2} \mathrm{SO}_{4}$. 4a was isolated by fractionated vacuum distillation; b.p. $80-85^{\circ} \mathrm{C}, 1$ mbar. Yield $13.30 \mathrm{~g}(75 \mathrm{mmol})$, $81 \%$ (based on $\mathbf{2 a}$ ).

IR (KBr, cm $\left.{ }^{-1}\right)$ : 3437 m; 3020 w; 2953 m; 2868 m; 1911 w; 1614 w; 1514 m; 1479 s; $1362 \mathrm{~s} ; 1179 \mathrm{~m} ; 1051 \mathrm{~s} ; 1007 \mathrm{~s} ; 820 \mathrm{~m} ; 760 \mathrm{~s}$.

${ }^{1} \mathrm{H} \mathrm{NMR}\left(\mathrm{CDCl}_{3}, \delta\right.$ in ppm): $0.88\left(\mathrm{~s}, 9 \mathrm{H},-\mathrm{C}\left(\mathrm{C}(7) \underline{\mathrm{H}}_{3}\right)_{3}\right) ; 2.31$ (s; $\left.3 \mathrm{H},-\mathrm{C}(1) \underline{\mathrm{H}}_{3}\right) ; 4.27$ (s, $1 \mathrm{H},-\mathrm{OH}$ ); 7.07 (d, J = $8 \mathrm{~Hz}, 2 \mathrm{H}, \operatorname{Ar}(\mathrm{C} 3) \underline{\mathrm{H}}) ; 7.17$ (d, J = 8.1 Hz, $2 \mathrm{H}, \operatorname{Ar}(\mathrm{C} 4) \underline{\mathrm{H}})$.

${ }^{13} \mathrm{C}$ NMR $\left(\mathrm{CDCl}_{3}, \delta\right.$ in ppm): $21.1\left(-\underline{\mathrm{C}}\left(\mathrm{CH}_{3}\right)\right) ; 25.9\left(-\mathrm{C}\left(\underline{\mathrm{CH}} \mathrm{H}_{3}\right)\right) ; 35.5\left(-\underline{\mathrm{C}} \mathrm{H}_{3}\right) ; 82.2$

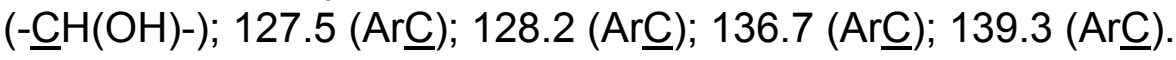

\section{Synthesis of bicyclo[2.2.1]hept-5-en-2-yl(4-methylphenyl)methan-1-ol, 4b}

The synthesis of $\mathbf{4 b}$ was performed as described for $4 \mathbf{a}$; b.p. $135^{\circ} \mathrm{C}, 0.8 \mathrm{mbar}$. Yield $22.00 \mathrm{~g}$ (102 mmol), 93\% (based on $\mathbf{2 b}$ ).

IR $\left(\mathrm{KBr}, \mathrm{cm}^{-1}\right): 3366$ s; 3055 s; 2960 s; 2868 s; 1902 w; 1614 w; 1513 s; 1446 m; $1335 \mathrm{~s} ; 1069 \mathrm{~m} ; 1015 \mathrm{~s} ; 884 \mathrm{~s} ; 718 \mathrm{~s}$.

${ }^{1} \mathrm{H}$ NMR $\left(\mathrm{CDCl}_{3}, \delta\right.$ in ppm): $0.4-3.2(\mathrm{~m}, 11 \mathrm{H}$, aliph. $\mathrm{C}(1,7,8,9,12,13) \underline{\mathrm{H}}) ; 3.7-4.2$ (two t (diastereoisomers), 1H, C(6)H); $5.8-6.1(\mathrm{~m}, 2 \mathrm{H}$, vinyl. $\mathrm{C}(10,11) \underline{H}) ; 6.9-7.2$ (m, $4 \mathrm{H}, \operatorname{Ar}(3,4) \underline{H})$.

${ }^{13} \mathrm{C} \mathrm{NMR}\left(\mathrm{CDCl}_{3}, \delta\right.$ in ppm): (aliph. $\underline{\mathrm{C}}$ :) $21.1 ; 29.3 ; 30.0 ; 30.2 ; 30.8 ; 41.8 ; 42.1 ; 42.2$; 42.8; 43.6; 44.2; 44.3; 44.6; 45.1; 45.4; 46.5; 46.9; 47.8; 49.2; 49.6; (- $\mathrm{CH}(\mathrm{OH})-): 78.1$; 78.7; 79.0; 79.5; (ArC:) 126.3; 126.5; 126.9; 129.0; 129.0; 132.3; 132.7; 137.1; 137.7; $140.2 ; 141.5$.

\section{Synthesis of 2,2,2-trifluoro-1-(4-methylphenyl)ethan-1-ol, $4 \mathrm{c}$}

To a stirred solution of $3(9.40 \mathrm{~g} ; 50 \mathrm{mmol})$ in $50 \mathrm{ml}$ of THF was added in 3 portions $0.76 \mathrm{~g}(20 \mathrm{mmol} ; 1.6 \mathrm{eq})$ of sodium borohydride at room temperature. The solution was refluxed for $3 \mathrm{~h}$, cooled to room temperature and stirred overnight. After adding carefully $20 \mathrm{ml}$ of hydrochloric acid $(2 \mathrm{M})$ the solution was poured into diethyl ether $(100 \mathrm{ml})$. The aqueous phase was extracted twice with $50 \mathrm{ml}$ of diethyl ether. The combined organic extracts were dried over anhydrous $\mathrm{Na}_{2} \mathrm{SO}_{4}$, filtered and dried in vacuum. The resulting yellow oil was purified by fractionated distillation; b.p. $55^{\circ} \mathrm{C}, 1$ mbar. Yield $7.60 \mathrm{~g} \mathrm{(40} \mathrm{mmol),} \mathrm{80 \%} \mathrm{(based} \mathrm{on} \mathrm{3).}$

IR (KBr, cm $\left.{ }^{-1}\right): 3381 \mathrm{~s} ; 3035 \mathrm{~m} ; 2928 \mathrm{~m} ; 1710 \mathrm{w} ; 1615 \mathrm{w} ; 1516 \mathrm{~m} ; 1269 \mathrm{~m} ; 1171 \mathrm{~s}$; $1128 \mathrm{~s} ; 1071 \mathrm{~m}: 807 \mathrm{~s} ; 696 \mathrm{~m}$. 
${ }^{1} \mathrm{H}$ NMR $\left(\mathrm{CDCl}_{3}, \delta\right.$ in ppm): 2.25 (s, $\left.3 \mathrm{H},-\mathrm{C}(1) \underline{\mathrm{H}}_{3}\right) ; 2.90$ (s, $\left.1 \mathrm{H},-\mathrm{C}(6) \underline{\mathrm{H}}(\mathrm{OH})-\right) ; 4.78$ (q, $\left.{ }^{3} \mathrm{~J}=12 \mathrm{~Hz}, 1 \mathrm{H},-\mathrm{C}(7) \underline{\mathrm{H}}-\mathrm{CF}_{3}\right) ; 7.08\left(\mathrm{~d},{ }^{3} \mathrm{~J}=8.1 \mathrm{~Hz}, 2 \mathrm{H}, \operatorname{Ar}(\mathrm{C} 3) \underline{\mathrm{H}}\right) ; 7.22$ (d, ${ }^{3} \mathrm{~J}=8.0 \mathrm{~Hz}$, $2 \mathrm{H}, \operatorname{Ar}(\mathrm{C} 4) \underline{\mathrm{H}})$.

${ }^{13} \mathrm{C} \mathrm{NMR}\left(\mathrm{CDCl}_{3}, \delta\right.$ in ppm): $21.6\left(-\underline{\mathrm{CH}}_{3}\right) ; 73.1$ (q, $\left.\mathrm{J}=32 \mathrm{~Hz} ;-\underline{\mathrm{C}} \mathrm{H}(\mathrm{OH})-\right) ; 124.7$ (q, ${ }^{1} \mathrm{~J}=$

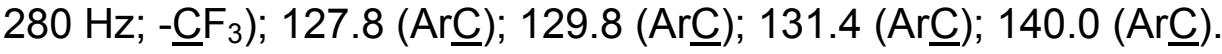

\section{Synthesis of 4-(1-chloro-2,2-dimethylpropyl)-1-methylbenzene, 5a}

A flask with stirring bar, reflux condenser and dropping funnel was charged with $11.17 \mathrm{~g}$ of $\mathrm{SOCl}_{2}(94 \mathrm{mmol} ; 1.3 \mathrm{eq}), 0.1 \mathrm{ml}$ of pyridine, and $100 \mathrm{ml}$ of toluene. $12.84 \mathrm{~g}$ of $4 \mathrm{a}(72 \mathrm{mmol})$ was dissolved in $80 \mathrm{ml}$ of toluene and added dropwise at $20^{\circ} \mathrm{C}$ to the reaction mixture. After completion of the addition, the mixture was heated to reflux for $3 \mathrm{~h}$. The reaction was cooled to $20^{\circ} \mathrm{C}$ and quenched by addition of $50 \mathrm{ml}$ of water. $60 \mathrm{ml}$ of tert-butyl methyl ether was added to the reaction mixture. This mixture was extracted with saturated aq. $\mathrm{Na}_{2} \mathrm{HCO}_{3}$ solution and finally with water. After separation of organic and aqueous phases, $\mathbf{5 a}$ was isolated by fractionated

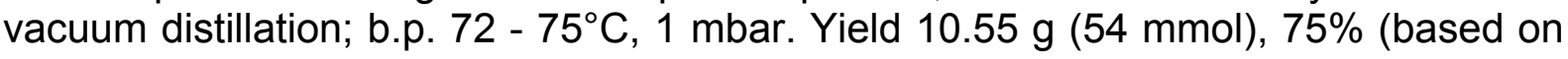
4a).

IR (KBr, cm $\left.{ }^{-1}\right)$ : 3024 m; 2972 s; 2869 m; 1911 w; 1613 w; 1513 s; 1479 m; 1365 s; $1255 \mathrm{~m} ; 1174 \mathrm{~m} ; 1021 \mathrm{w} ; 820 \mathrm{~s} ; 762 \mathrm{~s}$.

${ }^{1} \mathrm{H}$ NMR $\left(\mathrm{CDCl}_{3}, \delta\right.$ in ppm): $1.00\left(\mathrm{~s}, 9 \mathrm{H},-\mathrm{C}\left(\mathrm{C}(7) \underline{\mathrm{H}}_{3}\right)_{3}\right) ; 2.32\left(\mathrm{~s}, 3 \mathrm{H},-\mathrm{C}(1) \underline{\mathrm{H}}_{3}\right) ; 4.68$ (s, $1 \mathrm{H}, \quad-\mathrm{C}(6) \underline{\mathrm{HCl}}) ; 7.09$ (d, J=8.1 Hz, $2 \mathrm{H}, \quad \operatorname{Ar}(\mathrm{C} 3) \underline{\mathrm{H}}) ; 7.22$ (d, J=7.6 Hz, $2 \mathrm{H}$, $\operatorname{Ar}(\mathrm{C} 4) \underline{\mathrm{H}})$.

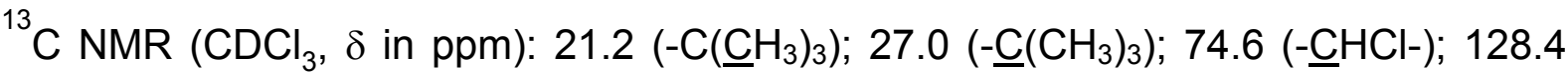

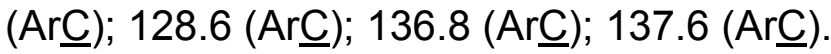

\section{Synthesis of 4-(bicyclo[2.2.1]hept-5-en-2-ylchloromethyl)-1-methylbenzene, $5 \mathbf{b}$}

The synthesis of $\mathbf{5 b}$ was performed as described for $\mathbf{5 a}$. b.p. $108-110^{\circ} \mathrm{C}, 0.2 \mathrm{mbar}$. Yield $20.00 \mathrm{~g}(86 \mathrm{mmol}), 86 \%$ (based on 4b).

IR (KBr, cm $\left.{ }^{-1}\right): 3054$ s; 2972 s; 2869 s; 1901 w; 1614; w; 1513 w; 1446 m; 1336 m; 1255 w; 1020 w; 819 m; 719 m.

${ }^{1} \mathrm{H}$ NMR $\left(\mathrm{CDCl}_{3}, \delta\right.$ in ppm): $0.3-3.2(\mathrm{~m}, 10 \mathrm{H}$, aliph. $\mathrm{C}(1,7,8,9,12,13) \underline{\mathrm{H}}) ; 4.0-4.4(\mathrm{~m}$, $1 \mathrm{H},-\mathrm{C}(6) \underline{\mathrm{H} C l}-) ; 5.6$ - 6.1 (m, $2 \mathrm{H}$, vinyl. $\mathrm{C}(10,11) \underline{\mathrm{H}}) ; 6.9-7.1(\mathrm{~m}, 4 \mathrm{H}, \operatorname{Ar}(3,4) \underline{\mathrm{H}})$.

${ }^{13} \mathrm{C}$ NMR $\left(\mathrm{CDCl}_{3}, \delta\right.$ in ppm): 21.0; 31.9; 32.4; 32.5; 33.4; 42.0; 42.3; 42.7; 42.9; 45.0;

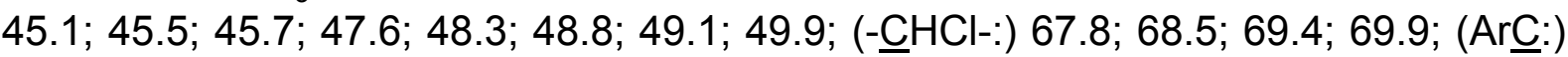
$126.9 ; 127.1 ; 127.3 ; 127.5 ; 128.6 ; 128.9 ; 131.2 ; 132.3 ; 136.2 ; 136.5 ; 137.0 ; 137.5$; $137.7 ; 137.8 ; 138.4 ; 138.6$.

\section{Synthesis of 4-(1-chloro-2,2,2-trifluoroethyl)-1-methylbenzene, 5c}

The synthesis of 5c was performed as described for 5a. m.p. $60-62^{\circ} \mathrm{C}$. Yield $5.40 \mathrm{~g}$ (26 mmol), 74\% (based on 5c).

IR (KBr, cm $\left.{ }^{-1}\right): 2977$ s; 2869 s; 1495 s; 1548 m; 1174 m; 1069 s; 911 m; 732 m. 
${ }^{1} \mathrm{H}$ NMR $\left(\mathrm{CDCl}_{3}, \delta\right.$ in ppm): $2.36\left(\mathrm{~s} ; 3 \mathrm{H}, \mathrm{C}(1) \underline{H}_{3}\right) ; 5.07\left(\mathrm{q},{ }^{3} \mathrm{~J}=7.1 \mathrm{~Hz}, 1 \mathrm{H}\right.$, $-\mathrm{C}(6) \underline{\mathrm{H} C l}) ; 7.20\left(\mathrm{~d},{ }^{3} \mathrm{~J}=8.1 \mathrm{~Hz}, 2 \mathrm{H}, \operatorname{Ar}(\mathrm{C} 3 / \mathrm{C} 4) \underline{\mathrm{H}}\right)$.

${ }^{13} \mathrm{C} \mathrm{NMR}\left(\mathrm{CDCl}_{3}\right.$, $\delta$ in ppm): $21.1\left(-\underline{\mathrm{CH}}_{3}\right) ; 58.7$ (q, $\left.{ }^{3} \mathrm{~J}=37.5 \mathrm{~Hz},-\underline{\mathrm{C}} \mathrm{HCl}-\right), 122.2$ (q, ${ }^{3} \mathrm{~J}=$

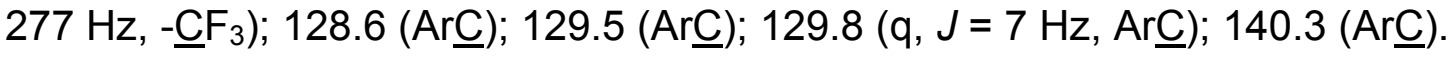

\section{Synthesis of poly(t-butyl-1,4-xylylene) (6a) by the Gilch route}

A flask equipped with stirring bar, reflux condenser and septum was charged with $6.73 \mathrm{~g}$ of potassium butanoate $(60 \mathrm{mmol})$ suspended in $300 \mathrm{ml}$ of THF. This mixture was degassed and heated to reflux. $5.90 \mathrm{~g}$ of $5 \mathrm{a}$ dissolved in $25 \mathrm{ml}$ of THF was injected rapidly to the reaction mixture. Heating was continued for $2 \mathrm{~h}$. Pouring into methanol quenched the hot reaction mixture. The polymer was isolated by filtration and was purified by repeated washing with water and methanol. Further purification was accomplished through reprecipitation from chloroform followed by drying in vacuum at $60^{\circ} \mathrm{C}$. Yield: $1.90 \mathrm{~g}(11.8 \mathrm{mmol}), 40 \%$.

$\mathrm{T}_{\mathrm{g}}=177^{\circ} \mathrm{C}, \mathrm{M}_{\mathrm{n}}=27500, \mathrm{M}_{\mathrm{w}}=56900,[\eta]=0.26 \mathrm{dl} / \mathrm{g}$.

IR (KBr, cm-1): 3044 m; 2951 s; 2968 m; 1512 m; 1477 m; 1393 m; 1365 s; 1226 w; 1102 w; 1020 w; 820 w; $571 \mathrm{~m}$.

${ }^{1} \mathrm{H}$ NMR $\left(\mathrm{CDCl}_{3}, \delta\right.$ in ppm): 0.87 (s, $\left.9 \mathrm{H},-\mathrm{C}\left(\mathrm{C}_{3}\right)_{3}\right) ; 2.36 \mathrm{ppm}\left(\mathrm{s}, 1 \mathrm{H},-\underline{\mathrm{C}}_{2}-\right) ; 2.72$ (s, $\left.1 \mathrm{H},-\underline{\mathrm{C}}_{2}-\right) ; 3.17(\mathrm{~s}, 1 \mathrm{H},-\mathrm{C} \underline{\mathrm{H}}(\mathrm{Ar})-) ; 6.5-6.8(\mathrm{~m}, 4 \mathrm{H}, \mathrm{Ar} \underline{\mathrm{H}})$.

${ }^{13} \mathrm{C} \mathrm{NMR}\left(\mathrm{CDCl}_{3}\right.$, $\delta$ in ppm): $28.5\left(-\mathrm{C}\left(\underline{\mathrm{CH}}_{3}\right)_{3}\right) ; 34.1\left(-\underline{\mathrm{C}} \mathrm{H}_{2}-\mathrm{CHAr}-\right) ; 36.3\left(-\underline{\mathrm{C}}\left(\mathrm{CH}_{3}\right)_{3}\right)$;

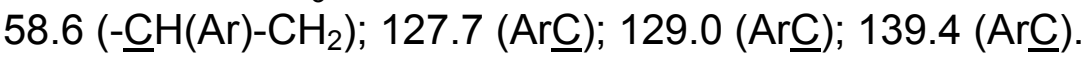

\section{Synthesis of poly(norbornenyl-1,4-xylylene) (6b) by the Gilch route}

The polyreaction was performed as described for $6 \mathrm{a}$. Yield: $0.55 \mathrm{~g}(2.8 \mathrm{mmol}), 28 \%$.

$\mathrm{T}_{\mathrm{g}}=136^{\circ} \mathrm{C}, \mathrm{M}_{\mathrm{n}}=17000, \mathrm{M}_{\mathrm{w}}=50600,[\eta]=0.17 \mathrm{dl} / \mathrm{g}$.

IR (KBr, cm $\left.{ }^{-1}\right): 3051 \mathrm{w} ; 2932 \mathrm{~s} ; 2861 \mathrm{~s} ; 1654 \mathrm{w} ; 1510 \mathrm{~s} ; 1443 \mathrm{~m} ; 1417 \mathrm{w} ; 1337 \mathrm{~m}$; 1252 w; 1103 m; 1019 w; 964 m; 833 w; 718 s.

${ }^{1} \mathrm{H}$ NMR $\left(\mathrm{CDCl}_{3}, \delta\right.$ in ppm): $0.4-3.2(\mathrm{~m} ; 10 \mathrm{H}$; aliph. $\underline{\mathrm{H}}) ; 5.7-7.9(\mathrm{~m} ; 11 \mathrm{H} ; \mathrm{Ar} \underline{\mathrm{H}}$ und vinyl.- $\underline{\text { H}})$.

${ }^{13} \mathrm{C} \mathrm{NMR}\left(\mathrm{CDCl}_{3}, \delta\right.$ in ppm): (aliph. $\underline{\mathrm{C}}$ :) $31.9 ; 32.7 ; 33.4 ; 35.7 ; 36.5 ; 37.6 ; 38.1 ; 39.1$; 39.3; 40.1; 41.4; 41.8; 42.2; 42.5; 42.9; 44.7; 45.0; 45.4; 45.7; 46.6; 47.4; 49.2; 49.4; 52.4; 53.1; 54.4; (vinyl. and ArC:) 125.3; 125.8; 127.4; 127.9; 128.3; 128.5; 128.6; 128.8; 129.0; 129.2; 129.5; 130.6; 131.8; 132.6; 133.7; 133.9; 134.6; 134.8; 135.3; $136.7 ; 136.8 ; 137.3 ; 137.9 ; 138.2 ; 139.6 ; 139.9 ; 141.5 ; 141.9$.

\section{Synthesis of poly(trifluoromethyl-1,4-xylylene) (6c) by CVD}

The quartz boat in the vaporization zone of the preheated $\left(800^{\circ} \mathrm{C}\right)$ pyrolysis apparatus (see ref. [10]) was charged under argon atmosphere with $1.89 \mathrm{~g}$ of $5 \mathrm{c}(7.2$ $\mathrm{mmol})$. The apparatus was evacuated and the pressure was kept between $0.2-0.4$ mbar. Films of $6 \mathbf{c}$ were formed at the glass walls of the tube behind the pyrolysis 
zone above the cooling trap. The product was dissolved in THF and reprecipitated in methanol and dried in vacuum at $80^{\circ} \mathrm{C}$. Yield: $0.60 \mathrm{~g}(3.5 \mathrm{mmol}), 70 \%$.

$\mathrm{T}_{\mathrm{g}}=89^{\circ} \mathrm{C}, \mathrm{M}_{\mathrm{n}}=14000, \mathrm{M}_{\mathrm{w}}=832300,[\eta]=0.85 \mathrm{dl} / \mathrm{g}$.

IR (KBr, cm $\left.{ }^{-1}\right): 3036$ m; 2964 m; 1514 m; 1376 s; 1171 s; 1328 s; 1020 w; 863 w; 805 $\mathrm{m} ; 682 \mathrm{w}$.

${ }^{1} \mathrm{H}$ NMR $\left(\mathrm{CDCl}_{3}, \delta\right.$ in ppm): $2.86(\mathrm{~s}, 1 \mathrm{H},-\mathrm{C} \underline{\mathrm{H}}(\mathrm{Ar})-) ; 3.16\left(\mathrm{~s}, 1 \mathrm{H},-\mathrm{C}_{2} 2^{-}\right) ; 3.21(\mathrm{~s}, 1 \mathrm{H}$, $\left.-\underline{\mathrm{H}}_{2}-\right) ; 3,67$ (d, - $\left.\mathrm{ArCH}_{2}-\mathrm{CH}_{2} \mathrm{Ar}-\right)$; 6.6 - 6.9 (s, $\left.4 \mathrm{H}, \mathrm{Ar} \underline{\mathrm{H}}\right)$.

${ }^{13} \mathrm{C} \mathrm{NMR}\left(\mathrm{CDCl}_{3}, \delta\right.$ in ppm): $35.2\left(-\underline{\mathrm{CH}}_{2^{-}}\right) ; 51.6\left(\mathrm{~m} ;-\underline{\mathrm{C}} \mathrm{H}\left(\mathrm{CF}_{3}\right)-\right) ; 127.5$ (q, ${ }^{1} \mathrm{~J}=280 \mathrm{~Hz}$,

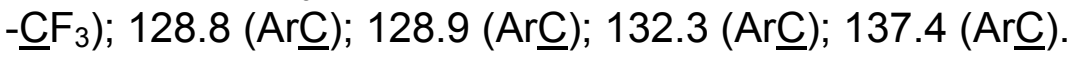

${ }^{19} \mathrm{~F}$ NMR $\left(\mathrm{CDCl}_{3}\right.$, $\delta$ in ppm): $-69.76\left(-\underline{C F}_{3}\right)$.

\section{Results and discussion}

\section{Synthesis of starting materials}

The starting materials (5) are based on $\alpha$-substituted xylenes, which were obtained by chlorination of corresponding alcohols 4 by thionyl chloride in the presence of pyridine (Scheme 1) [9]. 4 was synthesized either by reaction of $p$-tolyl bromide (1) with $\mathrm{Mg}$ and subsequent reaction with functionalized aldehydes (2) or by reduction of 3 (Scheme 1). Starting materials $\mathbf{5 a}$ - c were obtained in overall yields of $61 \%$ for $\mathbf{5 a}$, $69 \%$ for $\mathbf{5 b}$, and $32 \%$ for $\mathbf{5 c}$ and were characterized by IR and NMR analysis. Four different diastereoisomers are possible from each of these starting materials as shown in Scheme 2 for $\mathbf{4 b}$. Therefore, a complex splitting pattern was obtained in ${ }^{1} \mathrm{H}$ NMR spectra with many overlapping peaks for the monomers as shown in Fig. 1 for $\mathbf{4 b}$ and $\mathbf{5 b}$. The peak positions could not be assigned with certainty in ${ }^{1} \mathrm{H}$ NMR spectra just based on only 1D NMR measurements. Therefore, 2D COSY measurements were done for the correct assignment of peak positions in ${ }^{1} \mathrm{H}$ NMR. The representative COSY NMR of $4 \mathrm{~b}$ is shown in Fig. 1 . The four peaks obtained in the region 5.6 - $6.1 \mathrm{ppm}$ are assigned to vinylic hydrogens 10 and 11 (exo + endo diastereoisomers) based on the observation of ${ }^{1} \mathrm{H}-{ }^{1} \mathrm{H}$ cross peaks of proton 10 with protons 11 and 9 and that of proton 11 with protons 12 and 10 as marked in the COSY NMR spectrum (Fig. 2). Similarly, the unambiguity in the peak assignments in ${ }^{1} \mathrm{H} N M R$ is confirmed from the COSY spectrum, and the detail assignments of the cross peaks are given in Fig. 2. Although, with ${ }^{1} \mathrm{H}$ NMR and COSY experiments, the differentiation could not be made between the protons of different diastereoisomers, the peak positions could be assigned with certainty.

\section{Polymer synthesis}

$6 \mathrm{a}$ and $\mathbf{6 b}$ were obtained by the Gilch route with $\mathbf{5 a}$ and $\mathbf{5 b}$. $6 \mathrm{c}$ was obtained by CVD via vapor phase pyrolysis of 5c (Scheme 1). It should be mentioned that the conversion of $\mathbf{5 c}$ under the conditions of the Gilch route did not result in PPX which is most likely due to the competition of nucleophilic displacement of the chlorine substituents by the tert-butyl ether group of t-BuOK. On the other hand the CVD route using $\mathbf{5 a}$ and $\mathbf{5 b}$ did not result in PPXs which is most likely due to the undesired decomposition of these alkyl substituted starting materials under pyrolysis conditions. However, $6 \mathbf{a}$ was obtained from $5 \mathbf{a}$ via the Gilch route in a yield of $85 \%$. In contrast, 
6b was obtained only in a yield of $26 \%$ via the Gilch route which can be speculatively attributed to steric effects of the lateral norbornene substituent in $\alpha$-position. $6 \mathbf{c}$ was obtained by the CVD route in a yield of $63 \%$. In general, polymers 6 were soluble and fusible under feasible conditions, which allowed characterization by standard analytical techniques and processing from the melt or solution state. Molecular weight analysis was performed by GPC using universal calibration, which yielded molecular weights in close agreement with absolute molecular weights obtained by light scattering $[10,11]$. The molecular weight of $6 a$ was $M_{n}=27500 \mathrm{~g} / \mathrm{mol}$ and the polydispersity was $M_{w} / M_{n}=2.1$. Molecular weight of $6 \mathbf{b}$ was in a similar range $\left(M_{n}=\right.$ $17000 \mathrm{~g} / \mathrm{mol})$ with a somewhat higher polydispersity $\left(\mathrm{M}_{\mathrm{w}} / \mathrm{M}_{\mathrm{n}}=3.0\right)$. In contrast, the polydispersity of $6 c$ prepared by CVD was much higher $\left(M_{w} / M_{n}=59\right)$ with $M_{n}=$ $14000 \mathrm{~g} / \mathrm{mol}$. Enhanced polydispersities were observed for related CVD polyreactions, which is most likely due to the heterogeneous nature of the reaction and to experimental deviations (e.g. control of the rate of vaporization of starting materials, contact times in pyrolysis zone, rate of monomer deposition) [12]. Nevertheless, molecular weights of $\mathbf{6 a}-\mathbf{c}$ were high enough for the formation of solution-cast freestanding films which is an important criterion for application related issues.

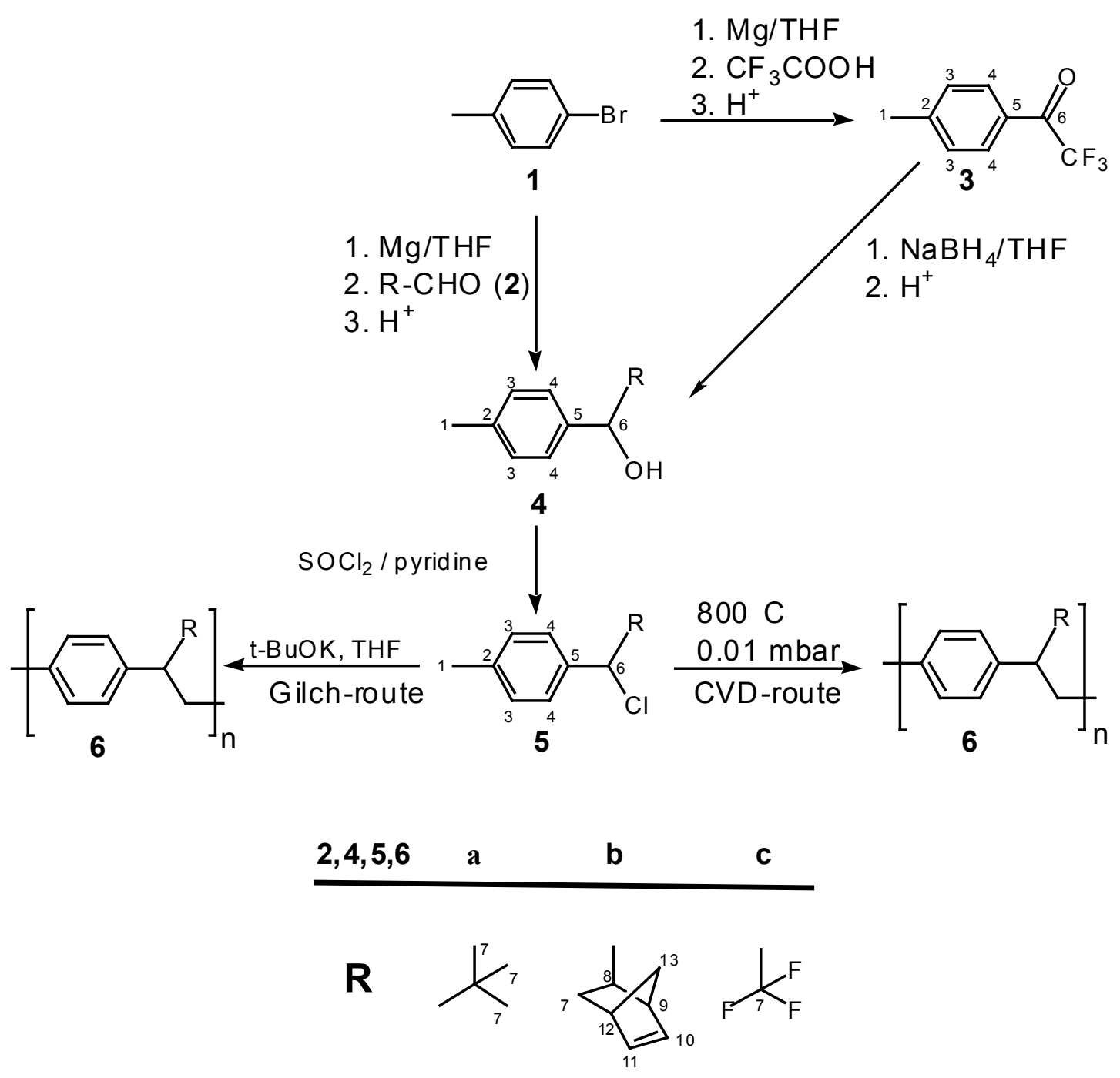

Scheme 1. Synthesis of starting materials and of polymers 


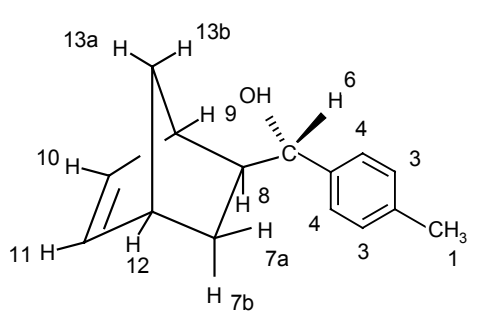

ExO-R

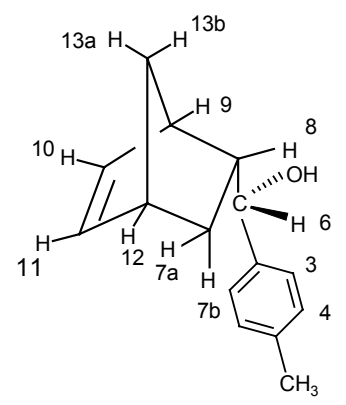

Endo-R

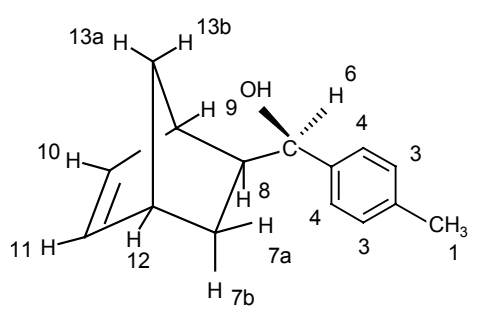

EXo-S

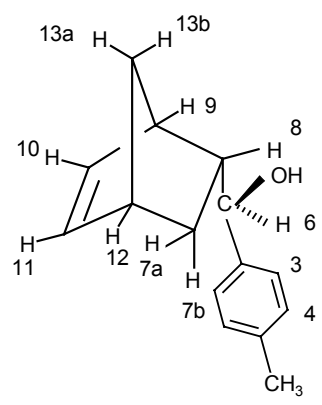

Endo-S

\section{Scheme 2. Different possible diastereoisomers}

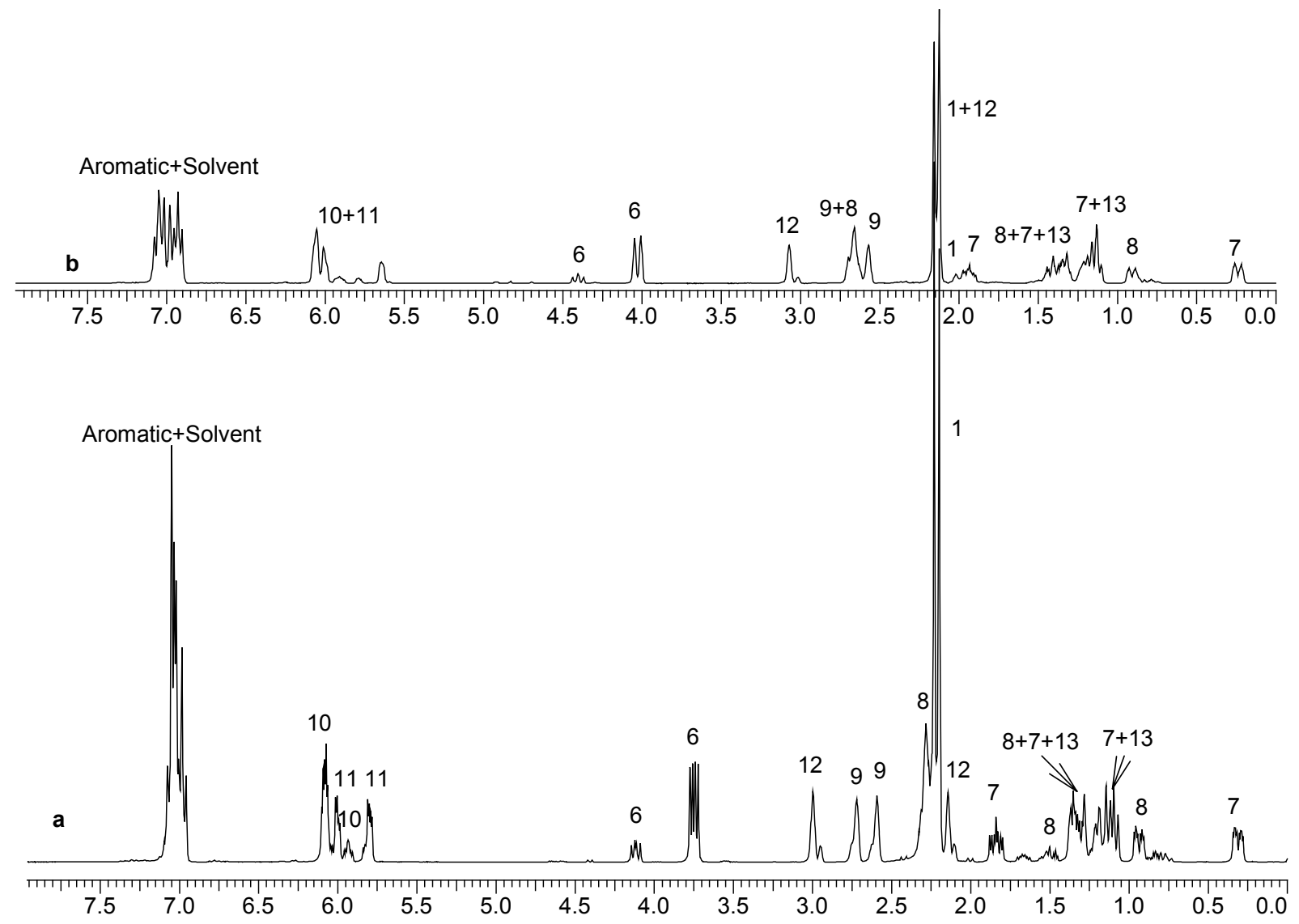

Fig. 1. ${ }^{1} \mathrm{H}$ NMR spectrum of (a) $4 \mathbf{b}$, (b) $5 \mathbf{b}$ 


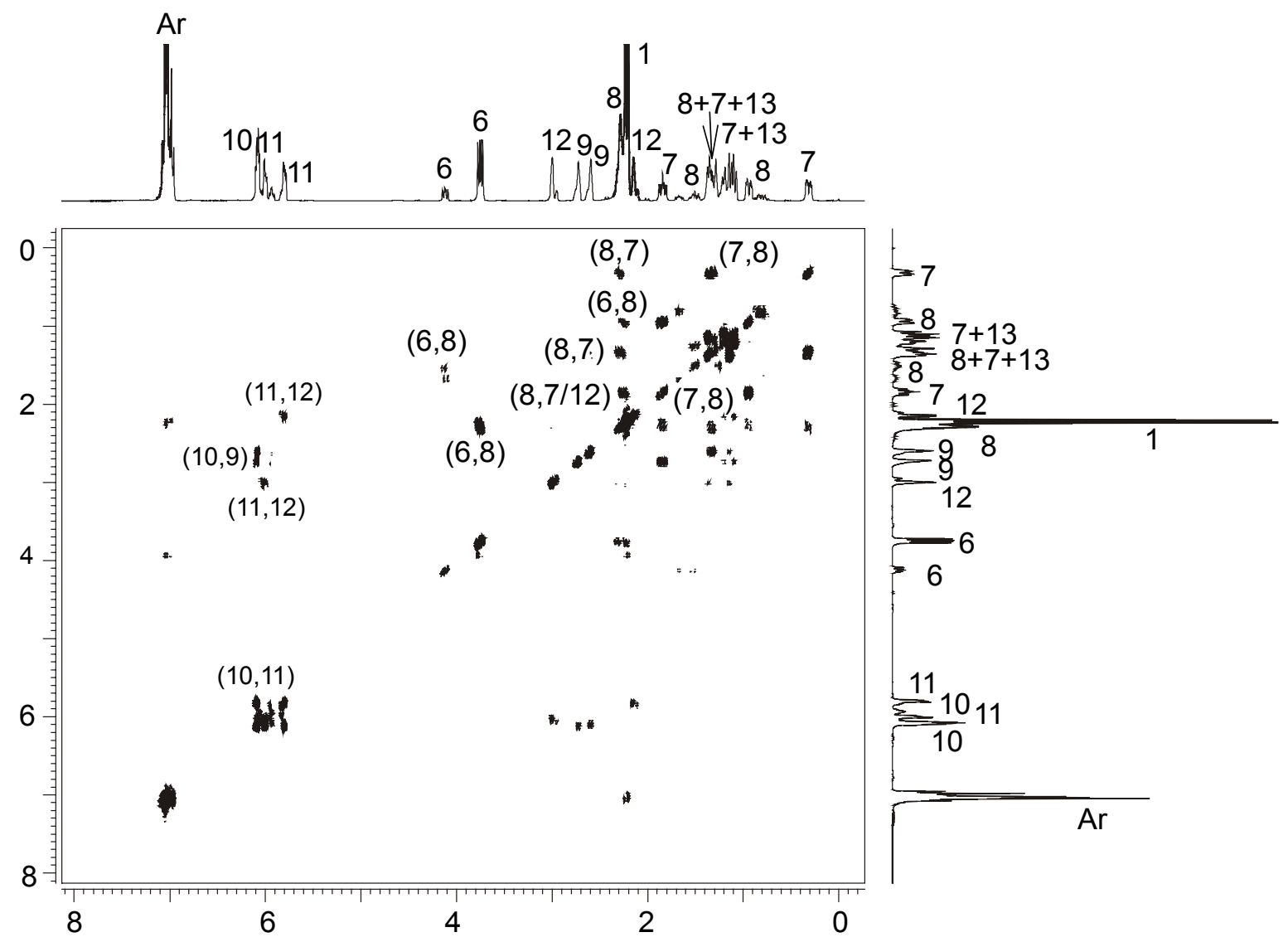

Fig. 2. COSY NMR spectrum of $\mathbf{4 b}$

The thermal properties of $\mathbf{6 a}$ - c are quite different. $5 \%$ weight loss of $6 \mathbf{a}$ occurred under nitrogen atmosphere (heating rate $20 \mathrm{~K} / \mathrm{min}$ ) at $367^{\circ} \mathrm{C}, 5 \%$ weight loss of $6 \mathbf{b}$ was observed at $436^{\circ} \mathrm{C}$, and for $6 \mathrm{c}$ even at $444^{\circ} \mathrm{C}$, which is closest to the thermal stability of unsubstituted PPX ( $5 \%$ weight loss by TGA, heating rate $20 \mathrm{~K} / \mathrm{min}$, at $488^{\circ} \mathrm{C}$ ). A similar stabilizing effect of $\mathrm{CF}_{3}$ groups was observed before for $4-\mathrm{CF}_{3^{-}}$ phenyl substituted PPXs [12].

The glass transition temperatures $\left(\mathrm{T}_{\mathrm{g}}\right)$ of $6 \mathbf{a}$ - $\mathbf{c}$ were obtained by DSC measurement from second heating runs (heating and cooling runs with $10 \mathrm{~K} / \mathrm{min}$ between 50 and $\left.300^{\circ} \mathrm{C}\right)$. $\mathrm{T}_{\mathrm{g}}$ of $6 \mathrm{a}$ was $177^{\circ} \mathrm{C}$ which is high in comparison to $6 \mathrm{~b}\left(\mathrm{~T}_{\mathrm{g}}=136^{\circ} \mathrm{C}\right)$ and $6 \mathrm{c}$ $\left(T_{g}=89^{\circ} \mathrm{C}\right)$. Indeed, $T_{g}$ of $6 a$ is even higher than $T_{g}$ 's of a variety of PPX derivatives with phenyl substituents in alpha position or as lateral substituents on the phenylene moiety $[6,12,13]$. Formation of isotropic melts was observed for $\mathbf{6 a}-\mathbf{6 c}$ by hot-stage microscopy about $20-30 \mathrm{~K}$ above $\mathrm{T}_{\mathrm{g}}$ (from DSC). DSC analysis of $\mathbf{6 a}-\mathbf{c}$ showed no endothermal signals in this temperature range which is a clear indication that as-polymerized $6 \mathbf{a}$ - c were amorphous.

\section{Conclusions}

Starting materials for the synthesis of $\alpha$-alkyl substituted PPXs can be synthesized in good to moderate yield by a two-step procedure. The choice of the synthetic route, either the CVD route or the Gilch route, depends to a large extent on the nature of the starting material. Three examples of PPXs with alkyl-substituents in $\alpha$-position were presented, which have their own merits. The tert-butyl-substituted PPX 6a 
presents a high glass transition temperature. The norbornenyl-substituted PPX $\mathbf{6 b}$ is a PPX derivate which opens perspectives for further chemical modifications due to its olefinic functionality. The $\mathrm{CF}_{3}$-substituted PPX $6 \mathrm{c}$ represents a promising aliphatic PPX derivative with remarkable thermal stability.

Acknowledgement: The authors are indebted to Deutsche Forschungsgemeinschaft and to Fonds der Chemischen Industrie for financial support.

[1] Iwatsuki, S.; Adv. Polym. Sci. 1984, 58, 93.

[2] Greiner, A.; Mang, S.; Schäfer, O.; Simon, P.; Acta Polym. 1997, 48, 1.

[3] Gorham, W. F. J.; J. Polym. Sci. A-1 1966, 4, 3027.

[4] Simon, P.; Greiner, A.; Polym. J. 1992, 24, 1317.

[5] You. L.; Yang, G.-R.; Lang, C.-I.: Wu, P.; Moore, J. A.; McDonald, J. F.; Lu, T. M.; Mater. Res. Soc. Symp. Proc. 1993, 282, 593.

[6] Schäfer, O.; Greiner, A.; Macromolecules 1996, 29, 6074.

[7] Lahann, J.; Klee, D.; Höcker, H.; Macromol. Rapid Commun. 1998, 19, 441.

[8] Lahann, J.; Langer, R.; Macromolecules, in press.

[9] Korshak, V. V.; Sosin, S. L.; Kristyakova, M. V.; Vysokomol. Soedin. 1959, 1, 937.

[10] Grubisic, Z.; Rempp, P.; Benoit, H.; J. Polym. Sci., Part B: Polym. Lett. 1967, 5, 753.

[11] Schmitt, R.; Bolle, B.; Greiner, A.; Heitz, W.; Makromol. Chem., Macromol. Symp. 1992, 61, 297.

[12] Ishaque, M.; Wombacher, R.; Wendorff, J. H.; Greiner, A.; e-Polymers 2001, no. 5.

[13] Simon, P.; Mang, S.; Hasenhindl, A.; Gronski, W.; Greiner, A.; Macromolecules 1998, 31, 8775. 